\title{
MAXIMUM THERMAL TOLERANCE OF TROPICAL MARINE GASTROPODS, Haliotis squamata (Reeve 1846)
}

\section{TOLERANSI SUHU MAKSIMUM DARI GASTROPODA LAUT TROPIS, Haliotis squamata (Reeve 1846)}

\author{
An Nisa Nurul Suci ${ }^{1}$, Dietriech Geoffrey Bengen ${ }^{2}$ and Neviaty Putri Zamani ${ }^{2 *}$ \\ ${ }^{1}$ Study Program of Marine Science, Graduate School, FPIK-IPB, Bogor, 16680, Indonesia \\ ${ }^{2}$ Department of Marine Science and Technology, FPIK-IPB, Bogor, 16680, Indonesia \\ *E-mail: npzamani@gmail.com
}

\begin{abstract}
Data about maximum thermal tolerance in marine organisms are needed to prevent the extinction of species due to global warming. The aim of this study is determining the maximum lethal temperature of Haliotis squamata. In this study, $H$. squamata were placed in individual containers and exposed to 5 different levels of temperature $\left(27^{\circ} \mathrm{C}, 28.5^{\circ} \mathrm{C}, 30^{\circ} \mathrm{C}, 31.5^{\circ} \mathrm{C}\right.$, and $\left.33^{\circ} \mathrm{C}, \mathrm{n}=20\right)$. The temperature was raised $0.5^{\circ} \mathrm{C}$ per 12 hours starting from ambient conditions until target temperatures were reached. The mortality was monitored since animals moved to the individual containers. The results showed that the maximum thermal limit of $H$. squamata is $31.5^{\circ} \mathrm{C}$ and $33^{\circ} \mathrm{C}$ is the lethal temperature, the temperature level with the lowest survival rate (0.15). The IPCC predict that sea surface temperature will raise up to $4^{\circ} \mathrm{C}$ and monthly average sea surface temperature in Indonesia is around $26-31^{\circ} \mathrm{C}$. That means in the next century average sea surface temperature could be more than the maximum thermal limit of $H$. squamata. Thus, early conservation is needed to protect $H$. squamata.
\end{abstract}

Keywords: abalones, conservation, elevated temperature, lethal temperature

\begin{abstract}
ABSTRAK
Data mengenai toleransi suhu maksimum organisme laut dibutuhkan untuk mencegah kepunahan yang dikarenakan oleh pemanasan global. Tujuan dari penelitian kali ini adalah untuk mengetahui toleransi suhu maksimum dari Haliotis squamata. H. squamata ditempatkan di dalam wadah individual yang memiliki perlakuan suhu berbeda $\left(27^{\circ} \mathrm{C}, 28,5^{\circ} \mathrm{C}, 30^{\circ} \mathrm{C}, 31,5^{\circ} \mathrm{C}\right.$, dan $\left.33^{\circ} \mathrm{C}, n=20\right)$. Suhu dinaikan $0,5^{\circ} \mathrm{C}$ setiap 12 jam. Mortalitas dihitung mulai dari setiap individu dipindahkan ke dalam wadah individual. Hasilnya memperlihatkan bahwa toleransi suhu maksimum H. squamata adalah $31,5^{\circ} \mathrm{C}$ dan $33^{\circ} \mathrm{C}$ sebagai suhu lethal yang merupakan level suhu dengan laju sintasan terendah $(0,15)$. IPCC memprediksi kenaikan suhu permukaan laut hingga $4^{\circ} \mathrm{C}$ di abad mendatang, sedangkan rata-rata suhu permukaan laut di Indonesia saat ini adalah $26-31^{\circ} \mathrm{C}$. Hal tersebut berarti bahwa di abad berikutnya rata-rata suhu permukaan laut Indonesia telah mencapai toleransi suhu maksimum dari H. squamata. Oleh karena itu, perlu dilakukan upaya konservasi dini dibutuhkan untuk melindungi keberlangsungan $H$. squamata.
\end{abstract}

Kata kunci: kenaikan suhu, kerang mata tujuh, konservasi, suhu mematikan

\section{INTRODUCTION}

Global warming is one of the factors that is affecting marine organism since most of them are ectotherm. IPCC assessedthat in the last 50 years temperature has raised about $0.11^{\circ} \mathrm{C}$ (IPCC, 2014). Temperature raise also monitored in Indonesia from 1982 until 2014 (Syaifullah, 2015). IPCC (2014) predicted in
2100 the sea water temperature will increase up until $4^{\circ} \mathrm{C}$ depending on emission production. Moreover, the strongest warming signal was found in the subtropical and tropical region (IPCC, 2014). One of the important marine tropical systems is Indonesia. In the present, the average sea surface temperature in Indonesia is about 26 $-31^{\circ} \mathrm{C}$ (Gaol et al., 2014). Combined with 
the prediction from IPCC, the highest sea surface temperature in Indonesia could reach $35^{\circ} \mathrm{C}$. Additionally, most of the tropical marine organisms already live nearby their upper thermal limit (Nguyen et al., 2011). Due to this, the most threatened marine organisms are the one living in the tropical region.

Several studies have been conducted to determine thermal tolerance and thermal sensitivity in the marine organisms. Thermal tolerance in invertebrate can be determined by lethal temperature (Dong et al., 2015). Furthermore, thermal sensitivity is mostly indicated by the expression of heat shock proteins (HSP). When the HSP increased, it indicates that the organism is under heat stress condition (Dutta and Mustafi, 2014; Tomanek and Sanford, 2003)

The response of a marine organism to water temperature change depends on the latitude of their distribution (Sotka and Giddens, 2009; Nguyen et al., 2011), in particular ectothermic organisms. Ectothermic organisms have sensitive responses to water temperature change because they cannot regulate their own body temperature, so the body temperature will follow the water temperature. In fact, water temperature affects physiological and metabolic responses that lead to different adaptation abilities (Gillooly et al., 2001). Thus, thermal tolerance varies between organisms.

The aim of this study is determining the maximum thermal tolerance of gastropods from the tropical region. Haliotis squamata, well known as abalone, has been chosen as the subject of this study because it is one of the ectothermic organisms that is distributed in the tropical region (Geiger, 1999). H. squamata is highly exploited for commercial reasons. In Indonesia, the fishermen usually catch $H$. squamata directly from the ocean. Thus, the stress pressure is coming not only from nature, such as global warming, but also from human. Conservation and awareness are needed to make $H$. squamata sustain and still consumed by the next generation. Furthermore, another aim of this study is creating awareness to the Indonesian government about the urgency of $H$. squamata conservation.

\section{RESEARCH METHODS}

\subsection{Time and Place of Research}

The experiment was conducted in Marine Habitat Laboratory, IPB University, Bogor. The experiment lasted for 13 days from $15^{\text {th }}$ until $27^{\text {th }}$ of June 2018. $H$. squamata was acquired from Balai Besar Riset Budidaya Laut dan Penyuluhan Perikanan (BBRBLPP) Gondol - Bali. The transport used the dry method with enough oxygen inside the bags.

\subsection{Animals}

$H$. squamata (shell length $20 \pm 1.1$ $\mathrm{mm}$, mean \pm standard deviation), used in this study were juveniles and reared in Balai Besar Riset Budidaya Laut dan Penyuluhan Perikanan (BBRBLPP) Gondol - Bali. First, animals were acclimated in laboratory codition and recovered from stress during transportation. They were maintained in four aquaria (400 mm x $750 \mathrm{~mm}$, filled with $10 \mathrm{~L}$ water) that has a biological filter in each aquarium. Each aquarium contained 25 animals that needed 5 days of recovery time before moved to individual containers. Recovery time ended when $H$. squamata did not produce mucus, ate their food and actively moved.

The experiment conducted in single individual containers $($ diameter $=120 \mathrm{~mm}$ ) filled with $1 \mathrm{~L}$ seawater and aerated using aeration stones for a sufficient oxygen supply. The individuals were chosen randomly from the aquarium and placed in a single individual container. Oxygen level, temperature, and salinity were controlled daily during the experiment. $50 \%$ of water inside individual containers was renewed daily and the debris (feces and food residue) were cleaned every morning. H. squamata fed ad libitum with algae pellets made out of 
Ulva powder and the pellets were replaced once a day.

\subsection{Temperature Treatment}

The experiment used 5 temperature levels $\left(27^{\circ} \mathrm{C}, 28.5^{\circ} \mathrm{C}, 30^{\circ} \mathrm{C}, 31.5^{\circ} \mathrm{C}\right.$, and $33^{\circ} \mathrm{C}, \mathrm{n}=20$ ) with $27^{\circ} \mathrm{C}$ as ambient temperature. The ambient temperature $\left(27^{\circ} \mathrm{C}\right)$ was chosen based on the monthly average lowest temperature in the last 8 years. We put individual containers inside a water-bath filled with water for each temperature level like illustrated in Figure 1. Heaters and heat regulator were used to control the water temperature inside the water-bath and individual containers. Temperature was monitored twice a day (in the morning and the afternoon) to make sure the temperature is stable. The temperature was monitored by HOBO logger inside the individual container. We put one HOBO logger in each temperature level.

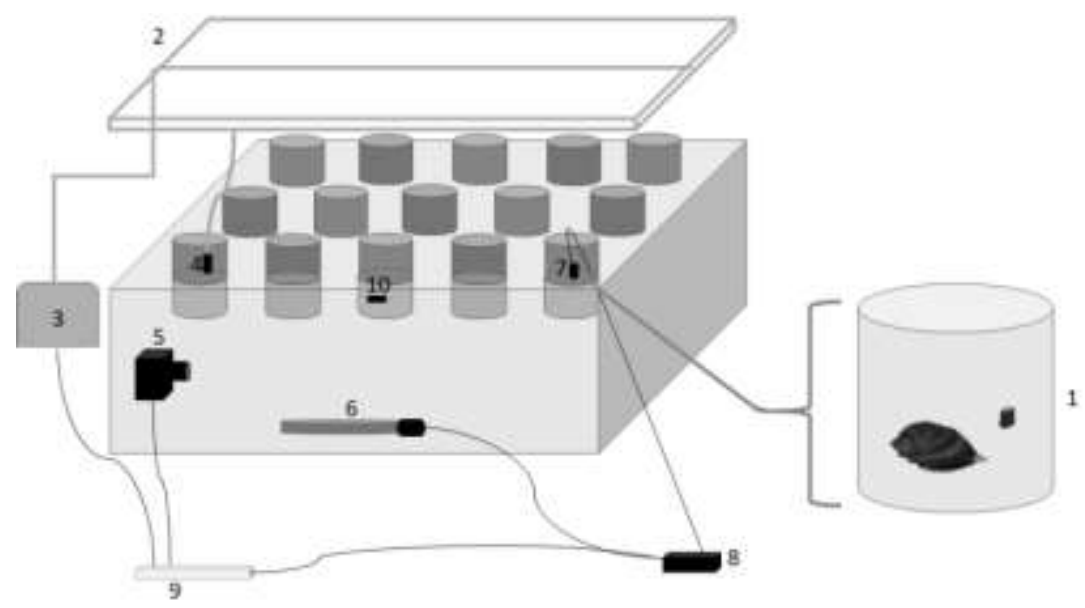

Figure 1. Experimental set up in one temperature level. 1: individual container contained an individual and a pellet, 2: aerator supply, 3: air pump, 4: aerator stone, 5: submersible pump, 6: heater, 7: temperature sensor, 8: heat regulator, 9: electricity supply, 10: HOBO logger.

The temperature was maintained at ambient temperature for 3 days after abalones were transferred into individual containers to ensure adaptation to experimental conditions. After 3 days, the temperature was raised $0.5^{\circ} \mathrm{C}$ per 12 hours. At the end, all temperature levels were in target temperature at the same time. The abalones were kept in target temperature for 5 days and survival was recorded. The mortality was observed since the abalones were moved to individual containers.

\subsection{Statistics Analysis}

The survival data was visualized in Kaplan-Meier graph (Dowd and Somero, 2013). Survival comparison between groups was tested using Peto-Wilcoxon test in $\mathrm{R}$ studio version 3.4.4. and we used $95 \%$ confidence interval. When the p-value > 0.05 , the null hypothesis was accepted, that means the hazard function is equal. In contrast, the null hypothesis was rejected when $\mathrm{p}$-value $<0.05$, that means the hazard function is not equal.

\section{RESULTS AND DISCUSSION}

\subsection{Results}

The highest mortality (17 individuals) occurred at the highest temperature level $\left(33^{\circ} \mathrm{C}\right)$. The abalones in highest temperature level mostly died after reached target temperature at day 11, 12, and 13 (Figure 2). The other individuals from different temperature levels didn't show any mortality after reaching target temperature. There were several abalones dying in the early stage of 
acclimation when the temperature still at $27^{\circ} \mathrm{C}$ in day 2 , day 3 , and day 4 . Some abalones also died at $31{ }^{\circ} \mathrm{C}$ and $32{ }^{\circ} \mathrm{C}$ in day 8 and day 9 , respectively.

Mortality occurred dramatically on temperature level 5. It's started from day 11 $(n=3)$ until the last day. At that time, the temperature regime has been already $33^{\circ} \mathrm{C}$. In this treatment, the $\mathrm{LT}_{50}$ was reached on day 12. The other temperature level just performed mortality until 2 individuals which are in temperature level $2\left(28.5^{\circ} \mathrm{C}\right)$ and level $3\left(30^{\circ} \mathrm{C}\right)$. Another temperature level that performed mortality is level 1 $\left(27^{\circ} \mathrm{C}\right)$ on day 4 . On the other hand, temperature level $4\left(31.5^{\circ} \mathrm{C}\right)$ is the only level with $100 \%$ survival, that means in this level there was no mortality observed.

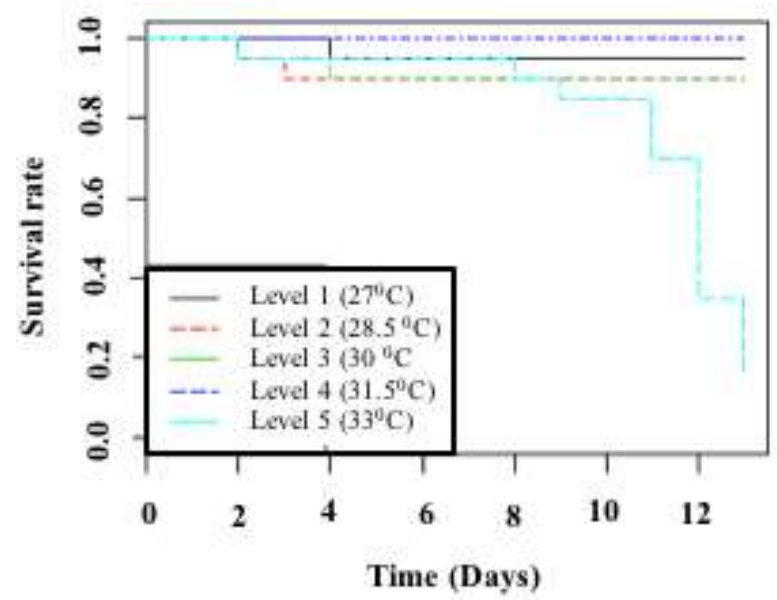

Figure 2. Survival in Haliotis squamata during exposure to different temperature levels $(n=20$, PetoWilcoxon test, $p<0.05$ ).

\subsection{Discussion}

Our study determined that the lethal temperature of $H$. squamata is $33^{\circ} \mathrm{C}$. The other study on three different species abalones, Haliotis discus, Haliotis gigantea, and their interspecific hybrid showed similarly lethal temperatures at $33^{\circ} \mathrm{C}$ (Chen et al., 2016). There is no contradiction between their data and our experiment regarding the lethal temperature. Thus, the maximum thermal tolerance of Haliotis is $33^{\circ} \mathrm{C}$. On the other hand, the highest survival is $31.5^{\circ} \mathrm{C}$ which only $1.5^{\circ} \mathrm{C}$ lower than the lethal temperature maximum. It happened because thermal tolerances of tropical species are narrow (Nguyen et al., 2011), so in that thermal regime $\left(31.5^{\circ} \mathrm{C}\right)$ the performances of $H$. squamata still in a good condition.

In the present study, the survival rate in temperature level 4 is the highest but we did not measure other variables such as growth rate, oxygen consumption rate, or metabolic rate. There is a possibility that they were in stress. Furthermore, enhanced temperature will increase the metabolic rate until it reaches its optimum temperature but if the temperature has passed the optimum, the metabolic rate will decrease until it reaches the lethal temperature (Gutow et al., 2016; Pörtner, 2001). Pörtner (2001) also said that decreasing metabolic rate can decline others performance, such as consumption rate and respiration rate, in ectotherm organism because the oxygen intake is not enough to cover enhance energetic demands. Moreover, under heat stress, the ectothermic organism will produce heat shock protein and will reduce the feeding time, thus lowering gastropod's metabolic rate and energy level (Tomanek and Sanford, 2003). Therefore, measuring growth rate, oxygen consumption and metabolic rate in temperature level 4 is needed to determine whether it is also the optimum temperature range for $H$. squamata or not.

$\mathrm{LT}_{50}$ of $H$. squamata in this study occurred after exposure to the highest temperature $\left(33^{\circ} \mathrm{C}\right)$ for one day. It showed that $33^{\circ} \mathrm{C}$ is really a critical temperature for $H$. squamata. In this state, metabolism of an organism is not normal. The energy demand increase in elevated temperature, so the metabolic rate also increase. In fact, there is a mismatch between metabolic rate and consumption rate (Lemoine and Burkepile, 2012). The consumption rate decrease in the lower temperature when the metabolic rate 
decrease. Furthermore, the mismatch slowly can reduce fitness in several taxa. In addition, we also observed less active $H$. squamata in the highest temperature level, which might be due to faster decreasing consumption rate compared to metabolic rate.

Monthly average sea surface temperature in Indonesia is around $26-31{ }^{\circ} \mathrm{C}$ (Gaol et al., 2014). IPCC prediction said that temperature will increase for $4^{\circ} \mathrm{C}$ in the next century (IPCC, 2014). It means that the monthly average sea surface temperature range in Indonesia will be enhanced to $30-$ $34^{\circ} \mathrm{C}$. That temperature range has passed the maximum thermal tolerance of $H$. squamata in this study. Alternatively, all living organisms have the ability to adapt to survive during changing habitat conditions. Marine Protected Area (MPA) is one of the solutions for mitigating ecosystems from global warming (Roberts et al., 2017). When the ecosystem is in good condition, the organisms in that habitat will not have more pressure from other kinds of stress, so the ability to adapt from any kinds of changes can be more effective. Thus, to prevent the extinction of $H$. squamata due to global warming, conservation in their habitat is needed.

Global warming will occur in long term, so we cannot just observe it in one life cycle or one generation of the species. We need to know how the elevated temperature can change their filial as well. The adaptation will be done by each organism. Furthermore, the adaptation ability can be transferred to their filial or not. Thus, the effect of elevated temperature also needs to be known in several generations.

\section{CONCLUSION}

The maximum limit temperature of H. squamata is $33^{\circ} \mathrm{C}$ which reached the $\mathrm{LT}_{50}$ on day 12 . On the other hand, the maximum survival happened in $31.5^{\circ} \mathrm{C}$ with $100 \%$ survival. The predicted temperature in
Indonesia will reach $34^{\circ} \mathrm{C}$. Moreover, conservation is needed to help adaptation and resilience of $H$. squamata.

\section{ACKNOWLEDGMENTS}

This study was sponsored by GAME (Global Approach by Modular Experiments) 2018, the collaboration research between the Department of Marine Science and Technology, IPB University and GEOMAR, Germany. We thank Dr. Mark Lenz from GEOMAR for help and advice. We also thank to Veronika Mitterwallner from Bayreuth University, Germany for helps during the experiment.

\section{REFERENCES}

Chen, N., X. Luo, Y. Gu, G. Han, Y. Dong, W. You, and C. Ke. 2016. Assessment of the thermal tolerance of abalone based on cardiac performance in Haliotis discus hannai, $H$. gigantean and their interspecific hybrid. Aquaculture, 465: 258-264. http://doi.org/10.1016/j.aquaculture.2 016.09.004

Dong, Y.W., G.D. Han, M. Ganmanee, J. Wang. 2015. Latitudinal variability of physiological responses to heat stress of the intertidal limpet Cellana toreuma along the Asian coast. Mar. Ecol. Prog. Ser., 529: 107-119.

Dowd, W.W. and G.N. Somero. 2013. Behavior and survival of Mytilus congeners following episodes of elevated body temperature in air and seawater. J. of Experimental Biology 216(3): 502-514. http://doi.org/10.1242/jeb.076620

Dutta, S.M. and S.B. Mustafi. 2014. Assessment of thermal stress adaptation by monitoring Hsp70 and MnSOD in the freshwater gastropod, Bellamya bengalensis (Lamark 1882). Environ Monit Assess, 8961-8967. 
http://doi.org/10.1007/s10661-0144057-2

Gaol, J.L., R.E. Arhatin and M.M. Ling. 2014. Pemetaan suhu permukaan laut dari satelit di perairan Indonesia untuk mendukung "One Map Policy". In: Hasyim et al. (eds). Prosiding Seminar Nasional Penginderaan Jauh 2014, International Convention Centre, Botani Square, Bogor, 21 April 2014. 433-442 pp.

Geiger, D.L. 1999. Distribution and biogeography of the recent Haliotidae (Gastropoda: Vetigastropoda) worldwide. Societa Italiana Di Malacologia. Parma.

Gillooly, J.F., J.H. Brown, G.B. West, V.M. Savage, E.L. Charnov. 2001. Effects of Size and Temperature on Metabolic Rate. Science, 293: 22482251.

Gutow, L., I. Petersen, K. Bartl, and K. Huenerlage. 2016. Marine mesoherbivore consumption scales faster with temperature than seaweed primary production. J. of Experimental Marine Biology and Ecology, 477: 80-85. http://doi.org/10.1016/j.jembe.2016.0 1.009

Intergovernmental Panel On Climate Change [IPCC]. 2014. Climate Change 2014: Synthesis Report. Contribution of Working Groups I, II and III to the Fifth Assessment Report of the Intergovernmental Panel on Climate Change. IPCC. Geneva. 151 p.

Lemoine, N.P. and D.E. Burkepile. 2012. Temperature-induced mismatches between consumption and metabolism reduce consumer fitness. Ecology, 93(11): 2483-2489.

Nguyen, K.D.T., S.A. Morley, C.H. Lai,
M.S. Clark, K.S. Tan, A.E. Bates, and L.S. Peck. 2011. Upper Temperature Limits of Tropical Marine Ectotherms : Global Warming Implications. PLOS ONE, 6(12): 1-8. http://doi.org/10.1371/journal.pone.00 29340

Pörtner, H.O. 2001. Climate change and temperature-dependent biogeography: oxygen limitation of thermal tolerance in animals. Naturwissenschaften, 88: 137-146.

Roberts, C.M., B.C. O'Leary, D.J. McCauley, P.M. Cury, C.M. Duarte, J. Lubchenco, D. Pauly, A. SaenzArroyo, U.R. Sumaila, R.W. Wilson, B. Worm, and J.C. Castilla. 2017. Marine reserve can mitigate and promote adaptation to climate change. PNAS, 114(24): 6167-6175.

Sotka, E.E. and H. Giddens. 2009. Seawater temperature alters feeding discrimination by cold-temperate but not subtropical individuals of an ectothermic herbivore. Biol. Bull, 216(1): 75-84. http://doi.org/10.1086/BBLv216n1p7 5

Syaifullah, M.D. 2015. Suhu permukaa laut perairan Indonesia dan hubngannya dengan pemansan global. J. Segara, 11 (1): 37-47.

Tomanek, L. and E. Sanford. 2003. HeatShock Protein 70 (Hsp70) as a biochemical stress indicator: an experimental field test in two congeneric intertidal gastropods (Genus: Tegula). Biol. Bull, 205(3): 276-284.

Received : 15 July 2019

Reviewed : 27 Auguts 2019

Accepted : 15 November 2019 